\title{
Crocodia Link (Peltigeraceae, Lobarioideae) in northern Argentinean rainforests
}

\author{
María Pía Rodríguez ${ }^{1,3}$ \& Andrea Michlig, ${ }^{1,3}$ \\ ${ }^{1}$ Instituto de Botánica del Nordeste (IBONE-UNNE-CONICET), Sargento Cabral 2131, CC 209, CP 3400 , \\ Corrientes, Argentina. E-mail: ma.pia.r89@gmail.com \\ ${ }^{2}$ Facultad de Ciencias Exactas y Naturales y Agrimensura (FACENA, UNNE), Av. Libertad 5470, CP 3400, \\ Corrientes, Argentina \\ ${ }^{3}$ Consejo Nacional de Investigaciones Científicas y Técnicas (CONICET), Argentina
}

\begin{abstract}
A revision of the lichen genus Crocodia Link in northern Argentinean rainforests is presented. Three species were identified for the region: C. arvidssonii (D.J. Galloway) D.J. Galloway \& Elix, C. aurata (Ach.) Link, and C. clathrata (De Not.) Trevis. The distribution range known for these species is extended: $C$. arvidssonii is recorded for the first time for the country; C. aurata for Corrientes, Misiones, and Salta provinces; and C. clathrata for Corrientes and Jujuy provinces. The morphology of each species is described and illustrated. A distribution map and a key to known species of the genus are also presented.
\end{abstract}

Keywords: Argentina, diversity, Peltigerales, Pseudocyphellaria

\section{INTRODUCTION}

The genus Pseudocyphellaria was proposed by Vainio (1890) to separate species of Sticta (Schreb.) Ach. with pseudocyphellae on the lower surface, with Pseudocyphellaria aurata (Ach.) Vain. (based on Sticta aurata Ach.) as type species. Recent molecular studies have shown it is a polyphyletic genus (Magain et al., 2012; Moncada et al., 2013, 2014). Moncada et al. (2014) recognized five different clades within it, among them the Crocodia clade. The name Crocodia, previously proposed by Link (1833), was then reinstated by Moncada et al. (2013) for $P$. aurata and P. clathrata (De Not.) Malme, based on molecular data. Galloway and Elix (2013), added to the genus the species $C$. arvidssonii (D.J. Galloway) D.J. Galloway \& Elix, C. poculifera (Müll. Arg.) D.J. Galloway \& Elix, and C. rubella (Hook. f. \& Taylor) Trevis., based on the morphological and chemical features.

Crocodia differs from Pseudocyphellaria in having a yellow medulla with pulvinic acid pigments and fernene or lupane triterpenoids as characteristic chemical components (Jørgensen \& Galloway, 2011; Galloway \& Elix, 2013). It is characterized by a foliose, usually large thallus, green algal photobiont, and internal cephalodia with cyanobacteria, yellow medulla with crystals, yellow pseudocyphellae on the lower surface, pedicellate and usually pubescent or verrucose apothecia, brown, fusiform-ellipsoid, 3-septate to rarely 5-septate, $18-35 \times 5-8 \mu \mathrm{m}$ ascospores; bacilliform, colourless, 3-4 $\mu \mathrm{m}$ long conidia; and fernane or lupane triterpenoids as characteristic chemical components (Galloway \& Elix, 2013; Moncada et al., 2013). It is a cosmopolitan genus, with its highest diversity in the Southern Hemisphere, in tropical and temperate regions, increasing its diversity in humid mountains rainforests (Galloway \& Elix, 2013). At present, it includes five species of which only two are recorded so far in Argentina: Crocodia aurata (as Pseudocyphellaria aurata) (Calvelo \& Liberatore, 2002; Lavornia et al., 2017) and Crocodia clathrata (as Pseudocyphellaria clathrata) (Santesson, 1942). A revision of this lichen genus in northern Argentinean forests was made aiming at increasing the knowledge of this genus in the country.

\section{MATERIAL AND METHODS}

Rainforests of northern Argentina are located in two disjunct areas within the South Brazilian and Parana dominions of the biogeographical regionalization of the Neotropical region (Morrone, 2014). These forests are divided into three biogeographic provinces: Yungas, Parana Forest, and Araucaria Forest (Fig. 1). The Yungas is 1ocated in northwestern Argentina, on the eastern slopes of the Andes mountain range, between 300 and $3500 \mathrm{~m}$, and is extended through Jujuy, Salta, Tucumán, and northern Catamarca 
Provinces (Cabrera, 1971; Morrone, 2014). Its predominant vegetation is the cloud forest. Within this province, three districts are distinguished: Transition Forests, Montane Jungles, and Montane Forests (Cabrera, 1971; Morrone, 2014; Oyarzabal et al., 2018). Parana Forest province, located in northeastern Argentina where it is extended through Misiones Provinces. The predominant vegetation is rainforests northward and savannas southward. In this province, two districts are distinguished: Campos and Mixed Forests (Cabrera, 1971; Cabrera \& Willink, 1973; Morrone, 2014). The Araucaria Forest province, with dominance of Araucaria angustifolia, is restricted to the eastern region of Misiones Province, between 600 to $850 \mathrm{~m}$ (Morrone, 2014).

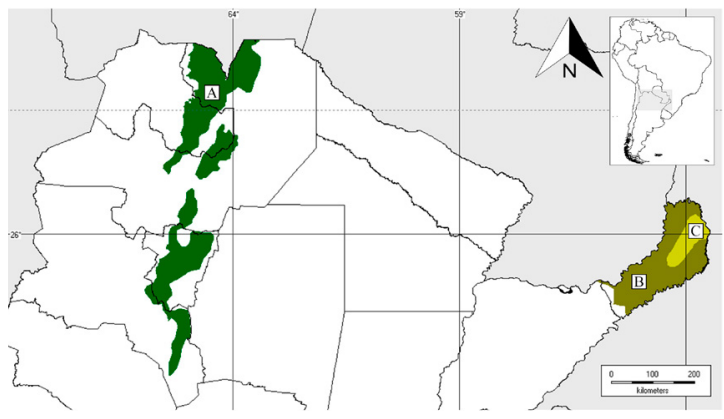

Fig. 1. Biogeographic provinces of northern Argentinean rainforests, A - Yungas; B - Parana Forest; C - Araucaria Forest.

Material from northern Argentina forests deposited at the herbarium of the Instituto de Botánica del Nordeste (CTES) was studied. Morphological and anatomical analyses were carried out using standard stereoscopic (Leica MZ6) and compound light microscopes (Leica CME). For anatomical study, thin sections of thallus, apothecia and pycnidia were cut by hand with a razor blade and then mounted in tap water for examination and thirty measurements of the different parts of the thallus (upper and lower cortex, photobiont layer, and medulla), apothecia (exciple, hypothecium, thecium, and epithecium), ascospores, and conidia were randomly made. These measurements were made with ImageJ software (Schneider et al., 2012). Lichen substances were identified with spots tests with $10 \% \mathrm{KOH}(\mathrm{K})$, sodium hypochlorite
(C), K followed by $\mathrm{C}(\mathrm{KC})$, and Steiner solution (P). In addition, specific and updated bibliography of the genus was consulted (Galloway \& Elix, 2013; Moncada et al., 2013, 2014). Subsequently, descriptions of species found in the area were made, including comments, illustrations, and maps of their distribution. In addition, a key to known Crocodia species is presented. The descriptions of Galloway $(1988,1994)$ and Galloway \& Elix (2013) for species that were not observed were used for the key (C. poculifera and C. rubella).

\section{RESULTS AND DISCUSSION}

Of 108 studied samples of Crocodia three species were identified: C. arvidssonii, C. aurata, and C. clathrata $(11,42$, and 55 specimens, respectively).

CRocodia ARvidssonir (D.J. Galloway) D.J. Galloway \& Elix. Australasian Lichenology 72: 34 (2013). (Fig. 3, A-C)

Description. Primary photobiont green algae. Thallus irregular to orbicular, up to $15 \mathrm{~cm}$ diam., branching pattern anisotomous to polytomous. Lobes horizontal to slightly ascendent, adjacent to imbricate, flat to undulate, with rounded to truncated, flat to revolute apices, (0.7-) 1-2 $(-3.5) \mathrm{mm}$ wide, margins sinuous to sometimes crenate, coriaceous. Upper surface scrobiculate to faveolate, yellowish brown to dark reddish in herbarium, pubescent towards the margins and apothecia base, without papillae, pruina and maculae. Cilia absent. Apothecia abundant, mainly marginal, aggregate, sessile, $1.5-7.5 \mathrm{~mm}$ diam.; disc dark red to brown, dull, concave, margin entire to crenate; amphithecium verrucose to pubescent, sometimes with pseudocyphellae, with yellow internal margin. Phyllidia abundant, marginal, aggregate towards the oldest part of the thallus, coralloid to palmate, up to $1.3 \mathrm{~mm}$ long, $1.4 \mathrm{~mm}$ wide, dorsiventrally flattened, squamiform to lobuliform, basal stalk flattened. Medulla yellow. Lower surface creamy yellowish to dark brown towards the center. Tomentum dense to the margin, short, sometimes long towards the center, spongy to pubescent at the margin, brown to white greyish at the margin. Rhizines absent. Pseudocyphellae yellow, numerous, up to 100 for $\mathrm{cm}^{2}$ towards the center of the thallus and up to $200 \mathrm{~cm}^{2}$ towards the 
margin, punctiform to irregular at center, margin with tomentum, (0.1-) 0.25-0.6 (-0.7) mm diam. towards the center of thallus. Cephalodia internal to erumpent at upper surface. Pycnidia numerous, laminal to sub-marginal, internal.

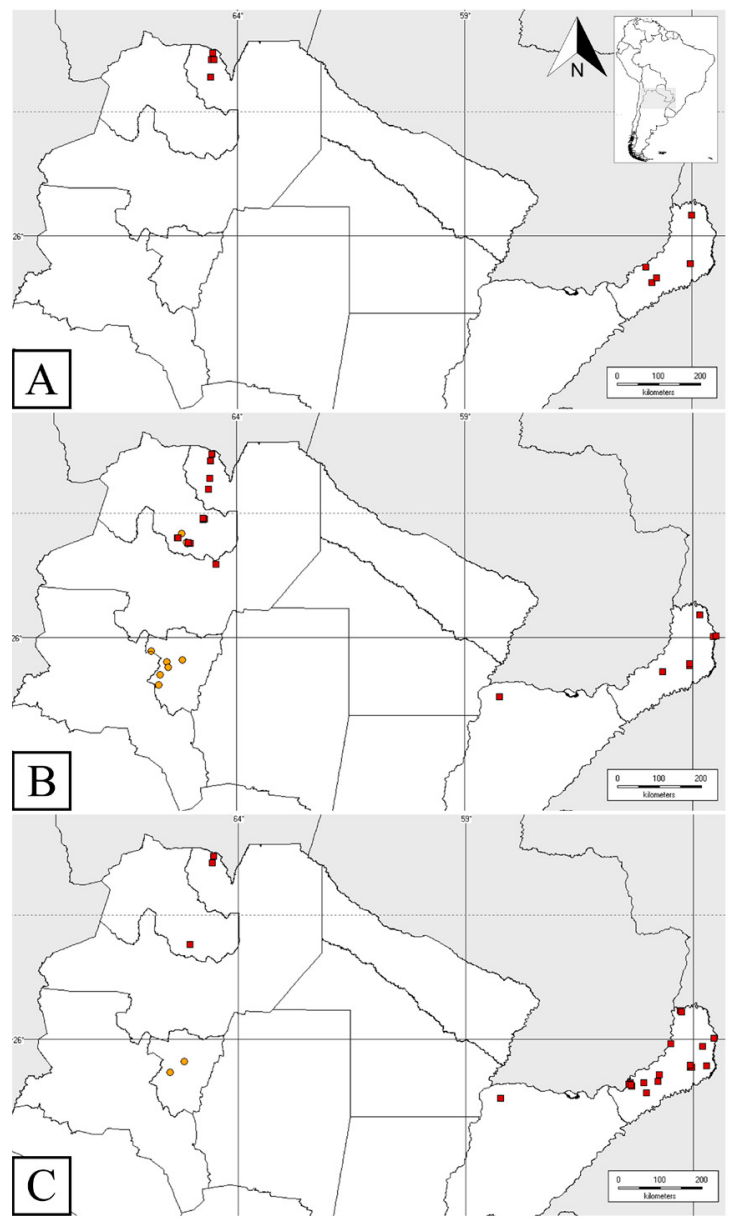

Fig. 2. Distribution of Crocodia species, $A-C$. arvidssonii; B - C. aurata; C - C. clathrata. Squares show studied specimens and dots those cited in literature.

Anatomy. Thallus (125-) 135-210 (-220) $\mu \mathrm{m}$ thick. Upper cortex paraplectenchymatous, (15-) 20-35 (-40) $\mu \mathrm{m}$ thick, cells 5.5-10.5 $\mu \mathrm{m}$ diam, wall $0.6-2 \mu \mathrm{m}$ thick, rounded to isodiametric, lumen 3.5-9 $\mathrm{\mu m}$ diam. Photobiont layer (15-) 20-30 (-35) $\mu \mathrm{m}$ thick. Medulla (55-) 65-100 $(-115) \mu \mathrm{m}$ thick, yellowish orange, hyphae 2$4 \mu \mathrm{m}$ thick, with orange crystals. Lower cortex paraplectenchymatous, (5-) 10-15 (-20) $\mu \mathrm{m}$ thick, 2-3 rows of cells; cells 6-11.5 $\mu \mathrm{m}$ diam, wall $0.7-2.5 \mu \mathrm{m}$ thick, rounded to isodiametric, lumen 4-9 $\mu \mathrm{m}$ diam. Upper tomentum absent. Lower tomentum up to $170 \mu \mathrm{m}$ long, septate, in fascicles of 12 hyphae together. Pseudocyphellae 118-175 $\mu \mathrm{m}$ diam. Apothecia: Exciple comprising cortex, photobiont layer and medulla, (187-) 219-312.5 (-406) $\mu \mathrm{m}$ thick. Hypothecium 45$50 \mu \mathrm{m}$ high, red-brown, K-. Thecium colourless to pale straw, 46-62 $\mu \mathrm{m}$ high. Epithecium brown-orange, 4-7 $\mu \mathrm{m}$ high. Ascospores fusiform-ellipsoid, brown, 3-septate at maturity, central two locules larger, end locules small and often irregular, (18-) 23-27 (-28) × 5-8 $\mu \mathrm{m}$. Conidia bacilliform, 2-3.5 $\mu \mathrm{m}$ long.

Chemistry. Cortex: $\mathrm{K}-; \mathrm{C}-; \mathrm{KC}-$ turning + red. Medulla: K-; C-; KC-; P-.

Specimens examined: ARGENTINA. Misiones. Dpto. Cainguás, Campo Viera, 19/10/1986, Daviña, J. 60, 61 (CTES); Campo Grande, 3 km road to Alba Pose, edge of forest, 25/11/1986, Cáceres S. 415 (CTES); Dpto. General Manuel Belgrano, Urugua-î Provincial Park, Dr. Luis H. Rolón trail, 02/06/2006, Michlig, A. \& Niveiro, N. 77 (CTES); Dpto. Guaraní, Predio Guaraní, edge of forest, $26^{\circ} 54^{\prime} 59^{\prime \prime}$, $54^{\circ} 12^{\prime} 18^{\prime \prime}$, Section I, 5/11/2000, Keller, H. 381 (CTES); Dpto. San Ignacio, Tabay falls, in forest, 12/1990, Popoff, O. 1070, 1071 (CTES). Salta. Dpto. Orán, San Andrés Country State, in Yungas, secondary forest, 2804'53'S, 6445'07'W, 28/10/1997, Schinini, A. 34118 A (CTES); Dpto. Santa Victoria, Baritú National Park, in front of "El Ukumar" camping, surroundings of cemetery, 20/04/2009, Ferraro, L. I. 8655 B (CTES), $i b$., margin of Lipeo river, surroundings of "El Ukumar" camping, on rocks and shrubs' bark, 21/04/2009, Ferraro, L. I. 8745 A (CTES); ib., rustic camping area "El Ukumar", descent to the river, right margin of Lipeo river, on a fallen branch, 22 $25^{\circ} 41.6^{\prime} \mathrm{S}, 4^{\circ} 41^{\prime} 19.3^{\prime} \mathrm{W}, 1124 \mathrm{~m}$, 21/04/2009, Michlig, A., Niveiro, N., Ferraro, L. I. \& Popoff, O. 1205 (CTES); ib., Los Toldos, El Nogalar Reserve, 23/04/2009, Ferraro, L. I. 8990 C (CTES).

Ecology and distribution. On bark and branches of trees and shrubs, rarely on rocks, in edge and interior forest. Known from Colombia, Ecuador, Peru, Bolivia (Galloway, 1989; Galloway 

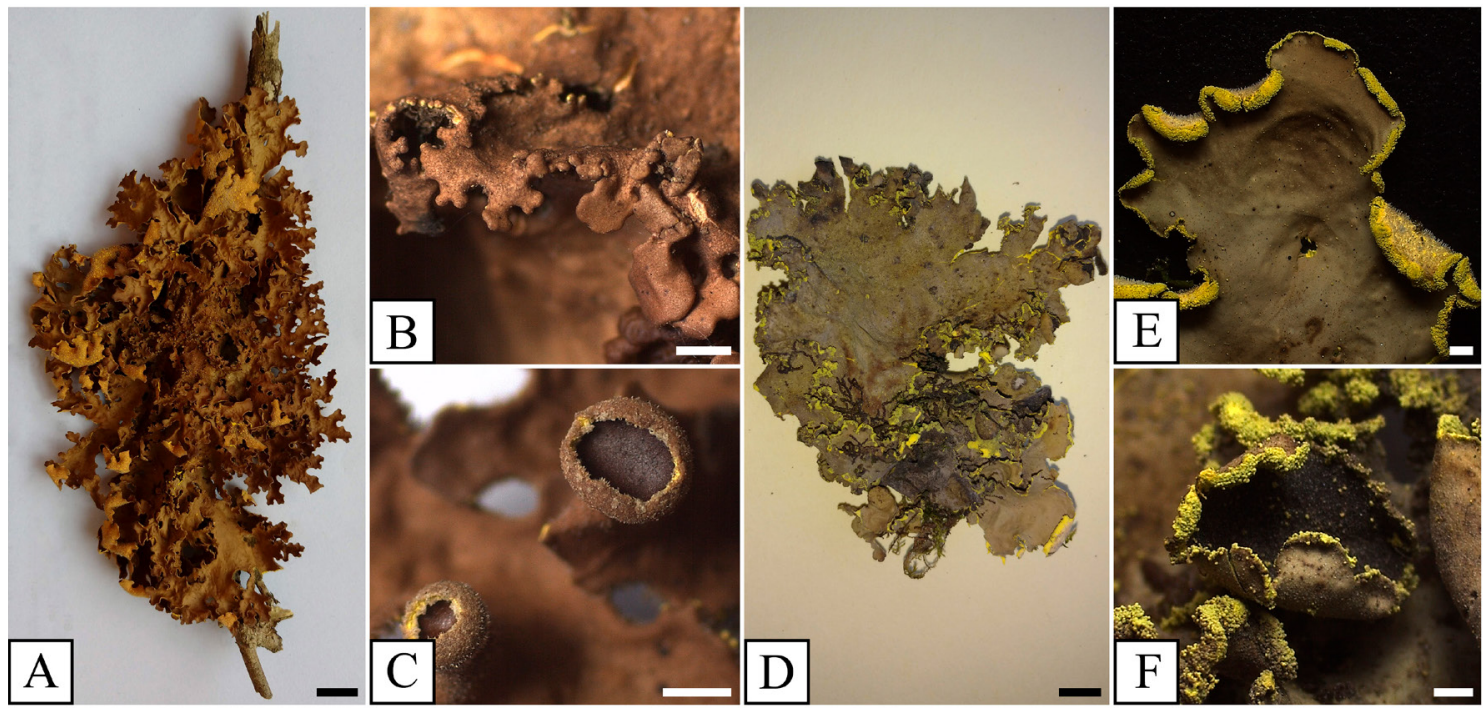

Fig. 3. A - C. Crocodia arvidssonii, A - complete thallus, B - marginal phyllidia, C - pubescent apothecia; D - F. Crocodia aurata, D - complete thallus, E - labriform soralia, F - apothecia with soralia. Scale bars: $A=1 \mathrm{~cm}, B=1 \mathrm{~mm}, C=1 \mathrm{~mm}, D=1 \mathrm{~cm}, E=1 \mathrm{~mm} \mathrm{\& F}=1 \mathrm{~mm}$.

\& Arvidsson, 1990; Sipman, 2002; Moncada \& Forero, 2006), and Islas Canarias (Tønsberg, 1999). This is the first record for Argentina, from Misiones and Salta Provinces (Fig. 2, A).

Comments. Galloway \& Arvidsson (1990) described Crocodia arvidssonii (under the name of Pseudocyphellaria arvidssonit) as a species with phyllidia that are delicately white-pubescent on the upper surface, differing from analyzed specimens in which no pubescence was observed. This material also differs in the absence of phyllidia on apothecial margins and pedicels. In addition, the thickness of the thallus, medulla, and lower cortex is thinner [(125-) 135-210 $(-220) \mu \mathrm{m},(55-)$ 65-100 (-115) $\mathrm{mm},(5-)$ 10-15 $(-20) \mu \mathrm{m}$, respectively] than reported by Galloway \& Arvidsson (1990) [150-350 (-440) $\mu \mathrm{m}$, (90-) 110-280 (-360) $\mu \mathrm{m}, 18-22(-27) \mu \mathrm{m}$, respectively].

Crocodia Aurata (Ach.) Link. Handbuch zur Erkennung der nutzbarsten und am häufigsten vorkommenden Gewächse 3: 177 (1833) (Fig. $3, \mathrm{D}-\mathrm{F})$

Description. Primary photobiont green algae. Thallus orbicular to irregular, up to $10 \mathrm{~cm}$ diam., polytomously branched. Lobes suborbicular to slightly ligulate, horizontal to slightly ascendent, adjacent to imbricate, flat to undulate, with their apices rounded, flat, becoming involute when sorediate, margins entire, (2-) 3-9 (-11) mm wide, coriaceous. Upper surface smooth to scrobiculate, green when wet, yellowish brown to dark reddish in herbarium, pubescent towards non-sorediate margins, without papillae, pruina and maculae. Cilia absent. Apothecia generally absent, when present marginal, aggregate, sub-pedicelate, (1-) 3-9 (-11) mm diam.; disc dark red to brown, dull, concave, margin crenate to denticulate; amphithecium verrucose to scabrid, sometimes with soralia. Soralia abundant, marginal, labriform; soredia granular. Medulla yellow. Lower surface white yellowish to brown centrally. Tomentum dense to the margin, short to the margin, spongy to pubescent at the margin, brown to white greyish at the margin. Rhizines absent. Pseudocyphellae yellow, numerous, up to 41-60 for $\mathrm{cm}^{2}$ towards the center of the thallus and up to $200 \mathrm{~cm}^{2}$ towards the margin, punctiform to irregular at center, margin with tomentum, (0.4-) 0.5-0.9 $(-1.2) \mathrm{mm}$ diam. towards the center of the thallus. Cephalodia internal to erumpent dorsally. Pycnidia laminal, immersed. 
Anatomy. Thallus 164-246 $\mu \mathrm{m}$ thick. Upper cortex paraplectenchymatous, 33-48 $\mu \mathrm{m}$ thick, cells 4-9 $\mu \mathrm{m}$ diam., cell wall 0.9-2.6 $\mu \mathrm{m}$ thick, with rounded to isodiametric lumina, cell lumina 3-7 $\mu \mathrm{m}$ diam. Photobiont layer 22-37 $\mu \mathrm{m}$ thick. Medulla 92-119 $\mu \mathrm{m}$ thick, yellowish orange, hyphae 1.5-3.5 $\mu \mathrm{m}$ thick, with orange crystals. Lower cortex paraplectenchymatous, 18.5$35 \mu \mathrm{m}$ thick, 3-4 rows of cells; cells 5-9.5 $\mu \mathrm{m}$ diam, cell lumina $3.3-8.8 \mu \mathrm{m}$ diam, cell wall 1.1-3.7 $\mu \mathrm{m}$ thick. Upper tomentum absent. Lower tomentum (175-) 200-250 (-268) $\mu \mathrm{m}$ long, solitary or in fascicles up to 10 hyphae together, hyphae branched. Pseudocyphellae 155-370 $(-510) \mu \mathrm{m}$ diam.

Apothecia. Exciple comprising cortex, photobiont layer and medulla, 165-245 $\mu \mathrm{m}$ thick. Hypothecium 45-50 $\mu \mathrm{m}$ high, red-brown, KThecium colourless to pale straw, $58-74 \mu \mathrm{m}$ high. Epithecium brown-orange, 7-15 $\mu \mathrm{m}$ high. Ascospores fusiform-ellipsoid, brown, 3-septate at maturity, (22-) 23-30 (-33) × 5-8 $\mu \mathrm{m}$. Conidia bacilliform, 2-3.5 $\mu \mathrm{m}$ long.

Chemistry. Cortex: $\mathrm{K}-; \mathrm{C}-; \mathrm{KC}-$ turning + red. Medulla: K-; C-; KC-; P-.

Specimens examined: ARGENTINA. Corrientes. Dpto. San Luis del Palmar, 5 route, $18 \mathrm{~km}$., southeast of San Luis del Palmar, 28/09/1975, Cristobal, C. L. \& Krapovickas, A. 1364 A (CTES). Jujuy. Dpto. Capital, Lagunas de Yala, in low valley, lichens on hillside, together with Parmelias, 02/11/1974, Ferraro, L. I. 446, 606 (CTES); $i b$. road to Tiroxi, 29 route, in Podocarpus forest, 03/11/1974, Ferraro, L. I. 472, 636 (CTES); ib., Lozano, road to Tiroxi, $3 \mathrm{~km}$ East of Grande river, 07/04/1980, Krapovickas, A. 36678 A, 36685, 36688 (CTES). Dpto. Ledesma, Calilegua National Park, Abra de Cañas, 1700 m, 06/03/2005, Ferraro, L. I., Popoff, O. \& Robledo, G. 7492 B (CTES), ib. Mesada de las Colmenas, on bark, Montane forest, 1150 m, 20/04/2019, Rodriguez, M. P. 285, 286 (CTES), ib., Abra de Cañas, in Bosque del Cielo trail, mixed with mosses, Montane forest, $23^{\circ} 40$ '56.5'S, 64 ${ }^{\circ} 54^{\prime} 05.4^{\prime \prime} \mathrm{W}$, 1700 m, 20/04/2019, Rodríguez, M. P. 312, 313, 314 (CTES). Dpto. Dr. Manuel Belgrano, Yala, entrance road to Potrero de Yala Provincial Park, 4 Provincial Route, on bark, 24 07'18.0'S, 65²7'14.1'W, 2276 m, 25/08/2018, Rodriguez, M.P.; Nuñez Florentín, M. \& Florentín, J. 254, 259, 260, 261, 268, 269, 273, 275 (CTES). Misiones.
Dpto. Cainguás. Aristóbulo del Valle, Salto Encantado Provincial Park, on bark, 27 03'33.5'S, 5449'35.5'W, 15/04/2018, Rodríguez, M. P., Ramirez, N., De Madrignac, B.; Niveiro, N. \& Ávalos A. 249, 250, 253 (CTES). Dpto. General Manuel Belgrano, Campiña de América, school, in forest, on side of road, $26^{\circ} 16^{\prime} 50$ 'S, 5342'19'W, 805 m, 09/12/2011, Michlig, A. et al. 2720 (CTES); Urugua-í Provincial Park, on route 101 , surroundings of the house of forest rangers, on bark, 25 48'34.3"S, 54 00'50.6'W, 15/04/2018, Rodríguez, M. P., Ramírez, N., De Madrignac, B., Niveiro, N. \& Ávalos A. 203 (CTES). Dpto. Guaraní, Predio Guaraní, trail to Soberbio stream, in "laurel" and "guatambú" forest with tree ferns, 09/09/1994, Schinini, A., Maruñak, V. \& Pellegrini, G. S/N (CTES), ib. near the guests housing, 09/1998, Tressens, S. 5992 (CTES); Yaboty Biosphere Reserve, Caa Yari Provincial Park, surroundings of the house of forest rangers, $26^{\circ} 52$ ' 19 'S, $54^{\circ} 13^{\prime} 33^{\prime \prime} \mathrm{W}, 526 \mathrm{~m}$, 10/12/2011, Michlig, A. et al. 2812 B (CTES). Dpto. San Pedro, Cruce Caballero Provincial Park, surroundings of the house of forest rangers, on bark, $26^{\circ} 15^{\prime} 40.6^{\prime}$ 'S, $53^{\circ} 38^{\prime} 55.6^{\prime} \mathrm{W}, 754 \mathrm{~m}$, 15/04/2018, Rodríguez, M. P., Ramírez, N., De Madrignac, B., Niveiro, N. \& Ávalos A. 238, 241 (CTES). Salta. Dpto. Anta, El Rey National Park, road to Los Lobitos, 26/03/2007, Ferraro, L. I. 8359 A (CTES); Dpto. Orán, San Andrés Country State, in Yungas, secondary forest, on "cebil", 2804'23"S, 6445'07'W, 28/10/1997, Schinini, A. 34141 (CTES); ib., "Duraznal”, foggy grassland environment in margin of San Andrés river, 16/XI/1998, Saravia Toledo, C. 14651 (CTES). Dpto. Santa Victoria, Baritú National Park, in front of "El Ukumar" camping, surroundings of cemetery, 20/04/2009, Ferraro, L. I. 8655 A, 8659 B (CTES), ib. rustic camping area "El Ukumar", descent to the river, right margin of Lipeo River, on fallen branches, $22^{\circ} 25^{\prime} 41.6$ ”'S, 6444'19.3'W, 1124 m, 21/04/2009, Michlig, A., Niveiro, N., Ferraro, L. I. \& Popoff, O. 1182 (CTES), ib., margin of Lipeo river, surroundings of "El Ukumar" camping, on rocks and shrubs' bark, 21/04/2009, Ferraro, L. I. 8745 B (CTES), $i b$., road to thermal springs, in Citrus plantation, on branches of a fallen tree, $22^{\circ} 25^{\prime} 23.3$ 's, 6444'39.9'W, 1180 m, 22/04/2009, Michlig, A. Niveiro, N., Ferraro, L. I. \& Popoff, O. 1429 (CTES), ib., Los Toldos, Reserva El Nogalar, 23/04/2009, Ferraro, L. I. 8986 B, 8990 A (CTES). 
Ecology and distribution: on the bark and branches of trees and shrubs, rarely on rocks, usually growing next to bryophytes, common in edge forests and on banks of rivers. Cosmopolitan species (Galloway \& Elix, 2013). In Argentina, it is distributed in Jujuy (Osorio \& Ferraro, 2001; Languasco et al., 2016; Lavornia et al., 2017), Tucumán (Grassi, 1950; Osorio, 1990), Río Negro (Malme, 1899), and Tierra del Fuego (Calvelo \& Liberatore, 2002). It is here recorded as new for Corrientes, Misiones, and Salta Provinces (Fig. 2, B).

Comments. The specimens analyzed lack of pruina on the upper surface differing from reported by Galloway (1988), although, this author consider this is a feature that could be influenced by particular microclimatic factors. In addition, apothecia are larger [(1-) 3-9 (-11) mm vs. 1-3 $(-5) \mathrm{mm}]$, and the thickness of the thallus, upper cortex, and photobiont layer is thinner (164$246 \mu \mathrm{m}, 33-48 \mu \mathrm{m}, 22-37 \mu \mathrm{m}$ respectively) than described by Galloway (1988) [(200-) 250-350 (-450) $\mu \mathrm{m},(40-)$ 45-70 (-80) $\mu \mathrm{m},(45-)$ 55-75 (-90) $\mu \mathrm{m}$, respectively].

Crocodia Clathrata (De Not.) Trevis. Lichenotheca Veneta 75 (1869) (Fig. 4, A-B)

Description. Primary photobiont green algae. Thallus irregular, up to $15 \mathrm{~cm}$ diam., branching polytomous. Lobes ligulate to flabellate, horizontal to ascendent, adjacent to imbricate, flat to undulate, with truncate, flat to slightly revolute apices, margins entire to sinuose, $1-5 \mathrm{~mm}$ wide, coriaceous. Upper surface scrobiculate to faveolate, bright green when wet to yellowish brown to dark reddish in herbarium, without upper tomentum, papillae, pruina and maculae. Cilia absent. Apothecia numerous, marginal, aggregate, pedicellate, basal invagination pronounced, (0.8-) 1.4-5.5 mm diam; disc dark red, dull, concave, margin revolute, entire to crenate; amphithecium verrucose to ciliate, with yellow internal margin. Vegetative propagules absent. Medulla yellow. Lower surface white to reddish yellow at the margin to brown centrally. Tomentum dense to the margin, short, sometimes long in the center, spongy to pubescent at the margin, brown to white greyish at the margin. Rhizines absent. Pseudocyphellae yellow, numerous, up to 61-100 for $\mathrm{cm}^{2}$ towards the center of the thallus and up to $200 \mathrm{~cm}^{2}$ towards the margin, punctiform to irregular at center, margin with tomentum, (0.1-) 0.2-0.4 (-0.6) $\mathrm{mm}$ diam. towards the center of the thallus. Cephalodia internal to erumpent at upper surface. Pycnidia laminal, internal, immersed.

Anatomy. Thallus 150-250 $\mu \mathrm{m}$ thick. Upper cortex paraplectenchymatous, (19-) 25-43 (-50) $\mu \mathrm{m}$ thick, cells 5.5-11 $\mu \mathrm{m}$ diam., wall 0.7-2.5 $\mu \mathrm{m}$ thick, with rounded to isodiametric lumina of 4-13 $\mu \mathrm{m}$ diam. Photobiont layer (23-) 30-50 (-66) $\mu \mathrm{m}$ thick. Medulla (50-) 75-149 (-203) $\mu \mathrm{m}$ thick, yellowish orange, hyphae 1.5-3 $\mu \mathrm{m}$ thick, with orange crystals. Lower cortex paraplectenchymatous, (14-) 33-50 (-60) $\mu \mathrm{m}$ thick, 2-4 rows of cells; cells $7.5-14 \mu \mathrm{m}$ diam., lumina of 5-12.5 $\mu \mathrm{m}$ diam., wall 1-4 $\mu \mathrm{m}$ thick. Upper tomentum absent. Lower tomentum (94-) 137-369 (-587) $\mu \mathrm{m}$ long, in fascicles of 12-20 hyphae together.
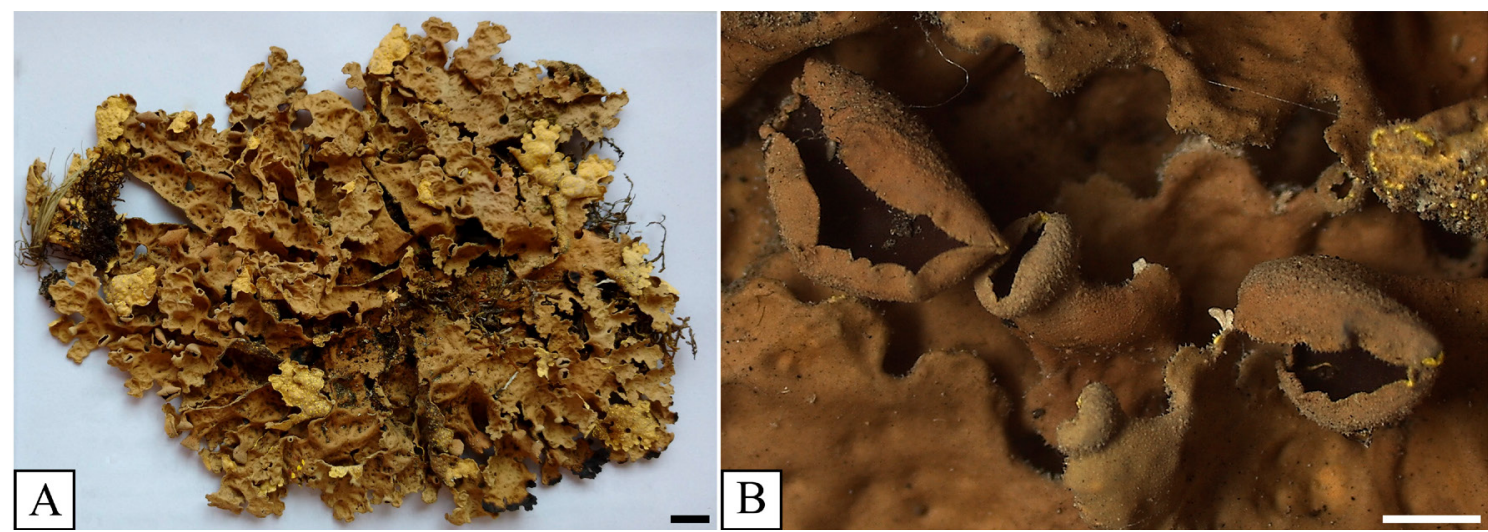

Fig. 4. A - B. Crocodia clathrata, A - complete thallus, B - marginal apothecia. Scale bars: $A=1 \mathrm{~cm}$ $\& \mathrm{~B}=1 \mathrm{~mm}$. 
Pseudocyphellae 212-262 $\mu \mathrm{m}$ diam. Apothecia: Exciple comprising cortex, photobiont layer and medulla, (42-) 66-100 (-166) $\mu \mathrm{m}$ thick. Hypothecium 42-66 $\mu \mathrm{m}$ high, red-brown, $\mathrm{K}-$. Thecium colourless to pale straw, (65-) 75-91 (-95) $\mu \mathrm{m}$ high. Epithecium brown-orange, 8-17 $\mu \mathrm{m}$ high. Ascospores fusiform-ellipsoid, brown, 3-4-septate at maturity (rarely 5 -septate), central two locules larger, end locules small and often irregular, (22-) 25-32 (-35) × 5-8 $\mu \mathrm{m}$. Conidia bacilliform, 2.5-5 $\mu \mathrm{m}$.

Chemistry. Cortex: K-; C-; KC-. Medulla: K-; $\mathrm{C}-$; KC-; P-.

Specimens examined: ARGENTINA. Corrientes. Dpto. San Luis del Palmar, route $5,18 \mathrm{~km}$, southeastern San Luis del Palmar, 28/09/1975, Cristobal, C. L. \& Krapovickas, A. 1364 B (CTES). Jujuy. Dpto. Capital, Lozano, road to Tiroxi, $3 \mathrm{~km}$ East of Grande river, 07/04/1980, Krapovickas, A. 36695 A (CTES). Misiones. Dpto. Cainguás, Campo Grande, $3 \mathrm{~km}$. south on the way to Alba Pose, edge of forest, 25/11/1986, Cáceres, S. 405 (CTES); Dpto. Candelaria, $1 \mathrm{~km}$ southeast of route 12, new road to Loreto, on bark of $\mathrm{Sa}$ pium, 11/12/1987, Vanni, R. \& Radovancich, A. 1130 A (CTES); Dpto. General Manuel Belgrano, Campiña de América, in forest on the side of the road, school, 26 $16^{\circ} 50$ 'S, 5342'19'W, $805 \mathrm{~m}$, 09/12/2011, Michlig, A. et al. 2724 (CTES); Dpto. General San Martín, Provincial Route 220, $21 \mathrm{~km} \mathrm{~N}$ of access Aristóbulo del Valle, interior of "monte", 01/08/1987, Vanni, R., Daviña, J., de Pompert, M. \& Radovancich, A. 1118 (CTES); Dpto. Guaraní, Predio Guarani, Section II, 2654'59"'S, 54¹2'18'W, 24/02/1993, Tressens et al. 4846 A, 4846 B (CTES); reserve of the faculty of Eldorado, surroundings of the residence, 22/11/1993, Popoff, O. 2136 A (CTES), ib. 22/02/1994, Tressens et al. 5504, 5505 (CTES), ib., Predio Guaraní, trail to Soberbio stream, in "laurel" and "guatambú" forest with tree ferns, 09/09/1994, Schinini, A., Maruñak, V. \& Pellegrini, G. s/n (CTES), ib., near the guest housing, on Sebastiania commensoniana, 09/1998, Tressens, S. 5989 (CTES), ib., Route 15 , between guest housing and Papel Misionero, in "laurel" forest, 26 $54^{\prime} 59$ "S, 54 $12^{\circ} 18^{\prime} \mathrm{W}$, 28/04/1999, Tressens, S., Ferraro, L. I., Keller, H., Maruñak, V. \& Revilla, V. 6255 (CTES), Yaboty Biosphere Reserve, Caa Yari Provincial Park, surroundings of the house of forest rangers, on “duraznero", 2652'19”S, 54¹3'33”W,
526 m, 10/12/2011, Michlig, A. et al. 2800, 2812 A (CTES); Dpto. Iguazú, Iguazú National Park, Macuco trail, on bark of Cecropia, 28/03/1995, Ferraro, L. I., Maruñak, V. \& Vanni, R. 4912 (CTES), ib., on the ground (fallen), 25 40'43.7'S, 54 26'56.5'W, 182 m, 10/10/2017, Rodriguez, M. P. \& Ramírez, N. 117 (CTES); ib., intangible trail entrance campsite, 31/03/1995, Ferraro, L. I., Maruñak, V. \& Vanni, R. 4965 (CTES), ib., Ñandú camping, 28/04/2004, Ferraro, L. I. \& Popoff, O. 7435 (CTES); ib., on bark, near the central station and La Selva restaurant ("Nuevo Centro"), 25 40'45.6”S, 54²7'10.7'W, $179 \mathrm{~m}$, 11/10/2017, Rodríguez, M. P. \& Ramirez, N. 124, 125, 126 (CTES); ib., on fallen branches, $25^{\circ} 42$ '11.2''S, 5425'32.1' W, $194 \mathrm{~m}$, 14/04/2018, Rodríguez, M. P., Ramirez, N., De Madrignac, B., Niveiro, N. \& Ávalos A. 199 (CTES); Dpto. Oberá, Salto Berrondo tourist complex, on bark, among mosses, 27²8'52.28'S, 55¹1'36.26”'W, 30/04/2017, Rodriguez, M. P. 75 (CTES). Dpto. San Ignacio, $1 \mathrm{~km}$ from the Quiroga house, towards the river, 18/12/1981, Ferraro, L. I., Cabral, E. \& Cáceres, S. 2229 (CTES), ib., edge of forest, 18/12/1981, Ferraro, L. I., Cabral, E. \& Cáceres, S. 2301 (CTES), ib., Teyú Cuaré fields, 18/12/1981, Ferraro, L. I., Cabral, E. \& Cáceres, S. 2363 (CTES), $i b$. Loreto ruins, in forest, 07/1987, Vanni et al. 1143 (CTES), ib., road to Guaraní community, near Osununú, on bark, 09/04/2018, Rodríguez, M. P., Ramirez, N., De Madrignac, B., Niveiro, N. \& Ávalos A. 180 (CTES); Dpto. San Pedro, Cruce Caballero Provincial Park, 17/05/2004, Sandoval, N. 18 (CTES), ib., 01/07/2004, Sandoval, N. 19 (CTES), ib., Yaboty Biosphere Reserve, Esmeralda Provincial Park, road to the pine forest, over a tree on the side of the trail, $26^{\circ} 53^{\prime} 40$ 'S, 5352'42'W, $318 \mathrm{~m}$, 15/05/2008, Michlig, A., Niveiro, N., Cabaña Fader, A. \& Salas, R. 774 (CTES); Salta. Dpto. Anta, El Rey National Park, forest of "tusco" and "piquillín" (road to Pozo Verde), on ground (xerophytic forest), 07/05/1983, Chalukian, S. 1937 (CTES), ib. Mirtaceae forest, on Cedrella sp., 09/05/1983, Chalukian, S. 1945 A (CTES), $i b$. , road to Los Lobitos, 26/03/2007, 8359 B (CTES); Dpto. Orán, San Andrés Country State, in Yungas, secondary forest, $28^{\circ} 04^{\prime} 23^{\prime \prime S}$, 6445'07'W, 28/10/1997, Schinini, A. 34118 B, 34119, 34140 (CTES), ib. foggy grassland environment in margin of San Andrés river, 2000 m, 16/11/1998, Saravia Toledo, C. 14655 
(CTES); Dpto. Santa Victoria, Los Toldos, epiphyte, on "lecherón" (Sapium haematospermum), 15/03/1986, Palaci, A. C. 417 (CTES), ib., Baritú National Park, in front of "El Ukumar" camping, surroundings of cemetery, 20/04/2009, Ferraro, L. I. 8659 A, 8660 B (CTES), ib., margin of Lipeo river, surroundings of "El Ukumar" camping, on rocks and shrubs' bark, 21/4/2009, Ferraro, L. I., 8765 (CTES), ib., rustic camping area "El Ukumar", descent to the river, right margin of Lipeo river, corticolous, $22^{\circ} 25^{\prime} 41.6^{\prime \prime} \mathrm{S}$, 644'19.3”W, 1124 m, 21/04/2009, Michlig, A., Niveiro, N., Ferraro, L. I. \& Popoff, O. 1175 (CTES), ib., road to thermal springs, on fallen branches, $22^{\circ} 25^{\prime} 38.1^{\prime \prime} \mathrm{S}, 64^{\circ} 44^{\prime} 24.7^{\prime} \mathrm{W}, 1230 \mathrm{~m}$, 22/04/2009, Michlig, A., Niveiro, N., Ferraro, L. I. \& Popoff, O. 1352, 1381 (CTES), ib., in Citrus plantation, on branches of a fallen tree, road to thermal springs, $22^{\circ} 25^{\prime} 23,3^{\prime \prime} \mathrm{S}, 64^{\circ} 44^{\prime} 39,9^{\prime \prime} \mathrm{W}$, 1180 m, 22/04/2009, Michlig, A., Niveiro, N., Ferraro, L. I. \& Popoff, O. 1404 (CTES), El Nogalar de los Toldos National Reserve, in front of the beginning of Santa Victoria trail, in Podocarpus forest, on a fallen branch, $22^{\circ} 16^{\prime} 46.6^{\prime \prime} \mathrm{S}$, 6442'35.0'W, $1677 \mathrm{~m}, 23 / 04 / 2009$, Michlig, A., Niveiro, N., Ferraro, L. I. \& Popoff, O. 1454 B, $1481 \mathrm{~B}, 1492$ (CTES), ib., right margin of Huaico Grande river, 22 ${ }^{\circ} 16^{\prime} 46.6^{\prime} \mathrm{S}, 64^{\circ} 42^{\prime} 35.0^{\prime \prime} \mathrm{W}, 1677$ m, 24/04/2009, Michlig, A., Niveiro, N., Ferraro, L. I. \& Popoff, O. 1532 B (CTES), ib., Los Toldos, El Nogalar Reserve, 23/04/2009, Ferraro, L. I., 8986 A, 8990 B, 8993 (CTES).

Ecology and distribution. On bark of trees and shrubs, on branches, rarely on soil, in interior and edge forest, rarely present in xerophytic forests. Cosmopolitan species (Galloway \& Elix, 2013). In Argentina, it was previously recorded from Misiones (Osorio, 1969, 1981), Río Negro (Santesson, 1942), Salta, and Tucumán Provinces (Osorio, 1990). It is here recorded as new for Corrientes and Jujuy Provinces (Fig. 2, C).

Comments. The spores observed in C. clathrata are larger [(22-) 25-32 (-35) × 5-8 $\mu \mathrm{m}]$ than those described by Galloway \& Arvidsson (1990) and Galloway \& Elix (2013) for the species [(15.5-) 18-20.5 (-22.5) × 3.5-4.5 $\mu \mathrm{m}$ and (15.5-) 20-20.5 (-22.5) × 3.5-4.5 $\mu \mathrm{m}$, respectively]. However, isotype of this species was studied and the size of the spores is similar to specimens examined in this article [(24-) 26-30 $(-32) \times 6-9 \mu \mathrm{m}]$.
Key to known Crocodia species

1. Vegetative propagules absent, apothecia commonly present ................ C. clathrata - Vegetative propagules present, apothecia rarely present .................................. 2

2. Thallus with marginal phyllidia

C. arvidssonii

- Thallus with soralia or isidia becoming sorediate 3

3. Thallus with coralloid isidia, more or less corticate at first but soon erode becoming sorediate; apothecia with granular-isidiate margins C. poculifera - Thallus with soralia; apothecia sometimes with sorediate exciple 4

4. Soralia strictly marginal, labriform; upper surface glabrous to minutely tomentose towards non-sorediate margins; apothecia, when present, verrucose to scabrid exciple C. aurata - Soralia mainly laminal, punctiform to confluent, with coarse soredia covering large areas of the thallus, and marginal, linear to sublinear or labriform soralia; upper surface tomentose from margins to centre, occasionally glabrous centrally, apothecia, when present, with a corrugatescabrid and tomentose exciple ... C. rubella

\section{CONCLUSION}

Crocodia species in northern Argentinean forests share characters such as growth form, photobiont, medulla and pseudocyphellae color, size and type of spores, and chemistry. However, they are easily distinguished as $C$. arvidssonii has marginal phyllidia and C. aurata labriform soralia, while C. clathrata lacks vegetative propagules. These species are commonly found together in tropical habitats and mountain forests (Galloway, 1989). As result of this study, we add one new record for Argentina (C. arvidssonii) and extend the distribution range of C. aurata (to Corrientes, Misiones, and Salta Provinces) and C. clathrata (to Corrientes and Jujuy Provinces). The remaining species of the genus, C. poculifera and $C$. rubella, share ecological preferences with studied species. However, their distribution range is different: C. poculifera is reported from East Africa, South-eastern Asia and Oceania (Galloway, 1994; Galloway \& Elix, 2013; de Lange \& Galloway, 2015) while C. rubella is known only from Australia and New Zealand 
(Galloway, 1988; Galloway \& Elix, 2013). Therefore, it is not expectably to find them in northern Argentinean forests.

\section{ACKNOWLEDGEMENTS}

We are grateful to the authorities of the Administración de Parques Nacionales (APN) of Argentina for providing collection permits. Dr. Niveiro for his collaboration in the collection trip and for suggestions on the manuscript. This work was funded by the Consejo Nacional de Investigaciones Científicas y Técnicas (CONICET) and the Secretaria General de Ciencia y Técnica (SGCyT-UNNE).

\section{REFERENCES}

Cabrera, A. L. 1971. Fitogeografia de la República Argentina. Boletín de la Sociedad Argentina de Botánica 1-2(14): 1-50. https://doi.org/ 10.31055/1851.2372.v50.n1

Cabrera, A. L. \& Willink, A. 1973. Biogeografía de América Latina. Monografía 13. Serie de Biologia. Secretaria General de la Organización de los Estados Americanos. Washington DC. EEUU. 120 pp.

Calvelo, S. \& Liberatore, S. 2002. Catálogo de los Liquenes de la Argentina. Kurtziana. 29(2): 1-4.

de Lange, P. J. \& Galloway, D. J. 2015. Lichen notes from the Kermadec Islands. I. Lobariaceae. Bulletin of the Auckland Museum 20: 141-170.

Galloway, D. J. 1988. Studies in Pseudocyphellaria (lichens) I. The New Zeland species. Bulletin of the British Museum (Natural History) 17: 2-267.

Galloway, D. J. 1989. Nomenclatural notes on Pseudocyphellaria IV: some South American taxa. Lichenologist 21: 88-89. https: / /doi.org/10.1017/ s0024282989000113

Galloway, D. J. 1994. Studies in Pseudocyphellaria (lichens) IV. Paleotropical species (excluding Australia). Bulletin of the Natural History Museum. London (Botany series) 24(2): 115-159.

Galloway, D. J. \& Arvidsson, L. 1990. Studies in Pseudocyphellaria (Lichens) II. Ecuadorean species. Lichenologist 22(2): 103-135. https://doi. org/10.1017/s0024282990000081

Galloway, D. J. \& Elix, J. A. 2013. Reinstatement of Crocodia Link (Lobariaceae: Ascomycota) for five species formerly included in Pseudocyphellaria Vain. Australasian Lichenology 72: 32-42.

Grassi, M. M. 1950. Líquenes foliosos y fruticulosos de Tucumán. Lilloa 24: 297-395.

Jørgensen, P. M. \& Galloway, D. J. 2011. Proposal to conserve Pseudocyphellaria, nom. cons. (Lobariaceae: Ascomycota) with a conserved type. Taxon 60: 1770-1771. https://doi.org/10.1002/ tax. 606022
Languasco, M. P., Izarduy, C. C., Leyría, N. V., Perera, T. C. \& Hladki, A. I. 2016. Catálogo de la colección histórica de liquenes de Marta Grassi depositados en el herbario LIL. Miscelanea 136: 3-26.

Lavornia, J. M., García, R. A., Rosato, V. G., Kristensen, M. J., Chayle, J. A. \& Saparrat, M. N. 2017. Aportes a la colección de hongos liquenizados del herbario del Instituto de Botánica Carlos Spegazzini (LPS). Boletín de la Sociedad Argentina de Botánica 52 (1): 5-12. https://doi. org/10.31055/1851.2372.v52.n1.16903

Link, D. H. F. 1833. Handbuch zur Erkennung der utzbarsten und am haufigsten vorkommenden Gewächse. Berlín. 3: 177-178.

Magain, N., Goffinet, B. \& Sérusiaux, E. 2012. Further photomorphs in the lichen family Lobariaceae from Reunion (Mascarene archipelago) with notes on the phylogeny of Dendriscocaulon cyanomorphs. Bryologist 115(2): 243-254. https:/ /doi. org/10.1639/0007-2745-115.2.243

Malme, G. O. A. 1899. Beiträge zur Stictaceen-flora Feuerlands und Patagoniens. Bihandg till k. svenska vet-akad hanglindar 25(6): 20. https:// doi.org/10.5962/bhl.title. 161888

Moncada, B. \& Forero, E. 2006. El género Pseudocyphellaria Vain. (Lobariaceae - Ascomycetes Liquenizados) en Colombia. Caldasia 28(2): 197-215.

Moncada, B., Lücking, R. \& Betancourt, L. 2013. Phylogeny of the Lobariaceae (lichenized Ascomycota: Peltigerales), with a reappraisal of the genus Lobariella. Lichenologist 45: 203-263. https:/ / doi. org/10.1017/s0024282912000825

Moncada, B., Reidy, B. \& Lücking, R. 2014. A phylogenetic revision of Hawaiian Pseudocyphellaria sensu lato (lichenized Ascomycota: Lobariaceae) reveals eight new species and a high degree of inferred endemism. Bryologist 117(2): 119-160. https://doi.org/10.1639/0007-2745-117.2.119

Morrone, J. J. 2014. Biogeographical regionalisation of the Neotropical region. Zootaxa 3782 (1): 001-110. https: //doi.org/10.11646/zootaxa.3782.1.1

Osorio, H. S. 1969. Contributions to the lichen flora of Argentina, II. Lichens from the province of Misiones. Comunicaciones Botánicas del Museo de Historia Natural de Montevideo 4(48): 1-5.

Osorio, H. S. 1981. Contribution to the lichen flora of Argentina XIII. Lichens from Misiones province. Comunicaciones Botánicas del Museo de Historia Natural de Montevideo 4(63): 1-18.

Osorio, H. S. 1990. Contribution to the lichen flora of Argentina. XVII. Lichens from Northwest Argentina. Comunicaciones Botánicas del Museo de Historia Natural de Montevideo 5(93): 1-5.

Osorio, H. S. \& Ferraro, L. I. 2001. Contribution to the lichen flora of Argentina. XX. Lichens from the Province of Jujuy. Comunicaciones Botánicas. $M u-$ seos Nacionales de Historia Natural y Antropología 118(6): 1-7. 
Oyarzabal, M., Clavijo, J., Oakley, L., Biganzoli, F., Tognetti, P., Barberis, I., Maturo, H. M., Aragón, R., Campanello, P. I., Prado, D., Oesterheld, M. \& León, R. J. C. 2018. Unidades de vegetación de la Argentina. Ecología Austral 28: 40-63. https:/ / doi.org/ 10.25260/EA.18.28.1.0.399

Santesson, R. 1942. Lichens from the Nahuel Huapi National Park in Argentine. Arkiv För Botanik. 30A(6): 1-12.

Schneider, C. A., Rasband, W. S. \& Eliceiri, K. W. 2012. NIH Image to ImageJ: 25 years of image analysis. Nature methods 9(7): 671-675. https:// doi.org/10.1038/nmeth.2089
Sipman, H. J. M. 2002. The significance of the Northern Andes for lichens. The Botanical Review 68(1): 88-99. https://doi.org/10.1663/00068101(2002)068[0088:tsotna]2.0.co;2

Tønsberg, T. 1999. Pseudocyphellaria arvidssonii new to Africa and P. mallota new to North America. Bryologist 102(1): 128-129. https://doi.org/ $10.2307 / 3244475$

Vainio, E. A. 1890. Etude sur la classification naturelle et la morphologie des lichens du Brésil. Acta Societatis Pro Fauna et Flora Fennica 7(1): 1-256. https: / / doi.org/ 10.5962/bhl.title.2741 